\title{
Fiskeolje gunstig for hjertet
}

\author{
Omega-3-fettsyrene DHA og EPA \\ reduserer hjertedød, men effekt på \\ arytmi eller totaldødelighet kan ikke \\ påvises.
}

Det har lenge vært antatt at fiskeolje kan redusere risiko for hjertedød. Imidlertid har systematiske oversikter ikke vist entydige resultater, og nylige studier har ikke vært inkludert. Den optimale sammensetningen av omega-3-fettsyrer, som dokosaheksaensyre (DHA) og eikosapentaensyre (EPA), for å forebygge hjerte- og karsykdom er heller ikke kjent. Nå har kanadiske forskere gått systematisk igjennom litteraturen for å undersøke effekter av fiskeolje på hjertedød og arytmier (1).

Randomiserte, kontrollerte studier av fiskeolje som kosttilskudd ble valgt ut og omfattet 12 studier og rundt 33000 pasienter. I 11 av studiene ble det vist en signifikant effekt av fiskeolje på hjertedød, men dose-respons-relasjon for DHA og EPA ble ikke påvist. Det var ingen effekt av fiskeolje på arytmier eller totaldødelighet.

- Resultatene i metaanalysen er i stor grad avledet fra GISSI- og JELIS-studiene, som omfatter $92 \%$ av pasientmaterialet, sier overlege Asgeir Græsdal ved Lipidklinikken, Rikshospitalet. GISSI-studien viste en $45 \%$ reduksjon i plutselig hjertedød i omega-3-gruppen, mens en $19 \%$ reduksjon i det primære endepunktet i JELIS-studien hovedsakelig skyldes redusert fore-

\section{Interaktiv e-helse}

Bruk av Internett til helseformål øker stadig og blir også mer interaktiv. Det vil gi nye utfordringer for helsevesenet.

Undersøkelsen eHealth Trends omfattet nesten 15000 telefonintervjuer i to runder: våren $2005 \mathrm{og}$ høsten 2007. I tillegg til nordmenn ble et representativt utvalg av personer fra Danmark, Portugal, Tyskland, Hellas, Latvia og Polen intervjuet om sin bruk av Internett i forhold til helse $(1,2)$.

Undersøkelsen viste at folk i stadig større grad bruker nettet til helseformål. Andelen av nettbrukerne i de sju landene som hadde hentet helseinformasjon fra nettet, økte fra $42 \%$ i 2005 til $52 \%$ i 2007. De mest aktive er unge kvinner.

Undersøkelsen viste også at $47 \%$ av de spurte mente at Internett var en viktig kilde til helseinformasjon. Det er en økning fra $40 \%$ i 2005. Bruk av andre medier som TV, aviser og radio blir mindre viktig.

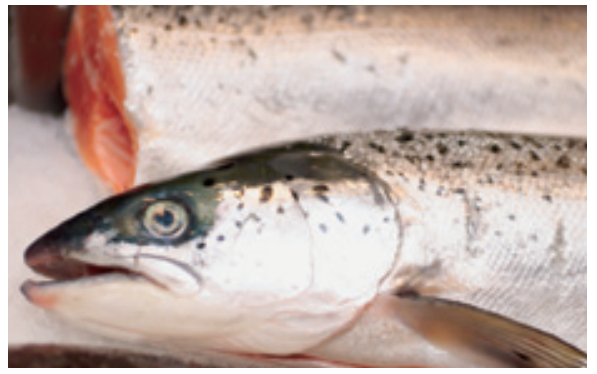

Illustrasjonsfoto Colourbox

komst av ustabil angina i behandlingsgruppen.

- I Japan er det lav forekomst av hjertedød, som kan ha medført manglende statistisk styrke til å vise effekt på totaldødelighet i JELIS-studien. I denne studien ble det imidlertid kun brukt EPA, mens det i GISSI-studien ble brukt en kombinasjon av EPA og DHA. OMEGA-studien, som snart skal publiseres, omfatter 4000 postinfarktpasienter og har plutselig hjertedød som primært endepunkt. Denne studien vil kunne gi nyttig informasjon om bruken av omega-3-fettsyrer i sekundærprofylakse, sier Græsdal.

\section{Trine B. Haugen}

trine.b.haugen@hf.hio.no

Tidsskriftet

Litteratur
1. León H, Shibata MC, Sivakumaran S et al. Effect of fish oil on arrhythmias and mortality: systematic review. BMJ 2008; 337: a2931.

Bruken av e-helse blir også mer interaktiv, og brukerne kommuniserer mer direkte med andre brukere, pasienter og helsepersonell. $23 \%$ av de som ble spurt i 2007 hadde brukt nettet på denne måten.

Dette vil gi nye utfordringer for både fastleger og spesialisthelsetjenesten, i og med at brukerne blir mer informert om helsespørsmål og i større grad vil forvente toveiskommunikasjon med helsevesenet over nettet.

\section{Per Egil Kummervold}

per.egil.kummervold@telemed.no Nasjonalt senter for telemedisin Troms $\varnothing$

\footnotetext{
Litteratur

1. Andreassen HK Bujnowska-Fedak MM, Chronak CE et al. European citizens' use of E-health services: a study of seven countries. BMC Public Health 2007; 7: 53

2. Kummervold PE, Chronaki CE, Lausen B et al. eHealth trends in Europe 2005-2007: a population-based survey. J Med Internet Res 2008; 10: e42. www.jmir.org/2008/4/e42 (17.1.2009).
}

\section{MiRNA fra virus}

Små RNA-molekyler som ikke translateres til proteiner er viktige i genreguleringen. Disse kalles miRNA, og i en ny studie har man nå identifisert miRNA fra virus som påvirker uttrykk av gener både hos mennesket og hos viruset selv (Nat Genet 2009; 41: 130-4).

Forskere unders $\varnothing$ kte hvilke gener som reguleres av miRNA fra herpesvirus 8 . Dette viruset er assosiert med Kaposis sarkom og uttrykker 17 ulike miRNA. Det humane genet $B C L A F 1$, som er involvert i regulering av apoptose, viste seg å være regulert av flere miRNA-varianter fra dette viruset.

Forskergruppen benyttet genuttrykksanalyser av ulike genmodifiserte cellesystemer. Etter å ha identifisert BCLAF1 som et kandidatgen, viste man at hvis virusets miRNA ble hemmet, gikk uttrykket av BCLAF1 opp og virusreplikasjonen økte.

\section{Fettstress og insulinresistens}

Hvordan fedme kan føre til insulinresistens er ikke fullt ut forstått, men ny forskning tyder på at inflammasjon i fettvev kan bidra til denne prosessen. Nå har amerikanske forskere studert metabolsk stressrespons i fettvev hos mus (Science 2008; 322: 1539-43).

Fettrik diett aktiverer det regulatoriske proteinet c-Jun NH2-terminalkinase-1 (JNK1), som kan føre til utvikling av insulinresistens. Hos mus som mangler dette proteinet selektivt i fettvev, ble den fettinduserte insulinresistensen i lever undertrykt. Nivået av interleukin-6 (IL-6) økte heller ikke i disse musene, som det gjorde i kontrollmus, mens for andre interleukiner eller adipokiner var det ingen forskjell. IL-6 kan forårsake insulinresistens, og behandling med IL-6 av musene som manglet JNK1 i fettvev, førte til insulinresistens i lever.

Resultatene tyder på at JKN1 kan være et mål for medikamentell behandling av metabolske sykdommer og at serumnivået av IL-6 kan være nyttig i evaluering av behandlingseffekten.

\section{Samfunnsbaserte psykiatriske helsetjenester best}

Godt utviklede psykiatriske helsetjenester i samfunnet er assosiert med lavere selvmordsrater enn sykehusbaserte tjenester. Det er konklusjonen av en finsk studie publisert i The Lancet (2008; 373: 147-53). I mange land har man arbeidet for å flytte de psykiatriske tjenestene fra sykehus til lokalsamfunnene, men uten at det har vært noe klart bevis som støtter dette.

Forfatterne analyserte psykiatriske helsetjenester i Finland i perioden september 2004-mars 2005. Analysen omfattet 428 regioner, og forfatterne beregnet selvmordsrisiko for hver region. 